International Journal of Scholarly Papers for Media and Communications

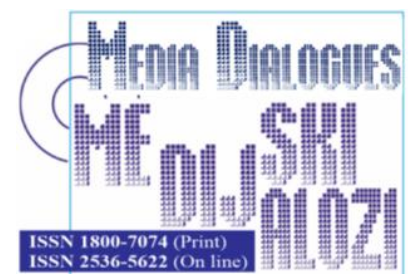

Ederstone, M.T. (2012), „Risk Management of the Apple Company”, Media Dialogues / Medijski dijalozi, Vol. 13, No. 3, pp. 35-43.

\title{
Risk Management of the Apple Company
}

\section{PhD MICHAEL T. EDERSTONE,}

Macquarie University,

Sydney, Australia

\begin{tabular}{|c|c|}
\hline $\begin{array}{l}A R T I C L E \\
\quad I N F O\end{array}$ & $\begin{array}{rll}\text { Received: december 27, } 2019 \text { / Revised from: January 25, } 2020 \\
\text { Accepted: February 25, } 2020 \text { / } & \text { Available online: July 15, } 2020\end{array}$ \\
\hline$D O I$ & doi.org/10.14254/1800-7074/13-3/3 \\
\hline
\end{tabular}

\begin{abstract}
Risk can be found everywhere. Man doesn't have to look and analyze very hard in order to find it. Many are saying that the world has becoming a riskier place. In terms of finance, there have been many people who are saying that the world has becoming more dangerous both for the indivi-duals who are engaged to the growing swings in the global equity markets as well as for big corporations that depends to the unpredictable changes. This paper discusses the basic concepts and categories associated with a risks, and particular emphasis is placed on risk management of the Apple company.
\end{abstract}

KEYWORDS: Apple, risks, risk management, strategies, innovations, communications. 


\section{INTRODUCTION}

As of now, there are many important variables and factors that can affect the overall performance of the company in terms of their relationship with their customers as well as other important entities who are involved in their supply chain. As of now, there are two most important factors that affect the position of a specific company in its respective industry as well as its position in the market, and that is globalization and innovation. The said two factors can give a tremendous impact to the competitive advantage of any company.

Globalization is considered as a multidimensional process that can help to broadly restructure as well as integrate the economy of the world, different institutions, together with the civil societies. It can also be considered as a forceful, continuing and accelerating process that helps to increase the different links and connections among the different actors, as well as the overall structures where in they operate, both inside states as well as across borders. Due to the help of globalization, trade, production as well as finance are now becoming more integrated in global manner, that before, it operates like global organizations and social movements. The said huge and wide relationships and connections helps to make the global interactions stronger and more complex (Clapp \& Dauvergne, 2005). Although globalization can help to improve competitive advantage, there are many risks that are associated in the said tactics. There are many barriers as well as factors that might affect the overall performance of the company due to globalization such as change and differences between the customers as well as the human resource.

Another important aspect is innovation or technology. The Internet is considered as the most used and the most important aspect of innovation and technology. Technology such as computers and other important hardware and software, enables many companies to have error-free and efficient transactions by having a centralized computerized system that can be used for decision-making processes. Innovation without risk is impossible, this is due to the fact that the process where in the risk is most naturally addressed in often manner is innovation. This is due to the fact that the process of replacing the old one with the new one often helps to make the world a safer place (Culp, 2001, p. 4).

\section{ABOUT RISKS}

Risk is the potential that a chosen action or activity (including the choice of inaction) will lead to a loss (an undesirable outcome). The notion implies that a choice having an influence on the outcome exists (or existed). Potential losses themselves may also be called "risks". Almost any human endeavor carries some risk, but some are much more risky than others. 
The Oxford English Dictionary cites the earliest use of the word in English (in the spelling of risque) as from 1621, and the spelling as risk from 1655. It defines risk as: (Exposure to) the possibility of loss, injury, or other adverse or unwelcome circumstance; a chance or situation involving such a possibility.

For the sociologist Niklas Luhmann the term risk is a neologism that appeared with the transition from traditional to modern society. In the Middle Ages the term risicum was used in highly specific contexts, above all sea trade and its ensuing legal problems of loss and damage. In the vernacular languages of the 16th century the words rischio and riezgo were used. This was introduced to continental Europe, through interaction with Middle Eastern and North African Arab traders. In the English language the term risk appeared only in the 17th century, and seems to be imported from continental Europe. When the terminology of risk took ground, it replaced the older notion that thought in terms of good and bad fortune.

The ISO 31000 (2009), ISO Guide 73,2002 definition of risk is the "effect of uncertainty on objectives". In this definition, uncertainties include events (which may or not happen) and uncertainties caused by a lack of information or ambiguity. It also includes both negative and positive impacts on objectives. Many definitions of risk exist in common usage, however this definition was developed by an international committee representing over 30 countries and is based on the input of several thou- sand subject matter experts.

\section{ABOUT RISK MANAGEMENT}

Risk management is the identification, assessment, and prioritization of risks followed by coordinated and economical application of resources to minimize, monitor, and control the probability and/or impact of unfortunate events or to maximize the realization of opportunities. Risks can come from uncertainty in financial markets, project failures (at any phase in design, development, production, or sustainment life-cycles), legal liabilities, credit risk, accidents, natural causes and disasters as well as deliberate attack from an adversary, or events of uncertain or unpredictable root- cause. Several risk management standards have been developed including the Project Management Institute, the National Institute of Science and Technology, actuarial societies, and ISO standards. Methods, definitions and goals vary widely according to whether the risk management method is in the context of project management, security, engineering, industrial processes, financial portfolios, actuarial assessments, or public health and safety.

The strategies to manage risk typically include transferring the risk to another party, avoiding the risk, reducing the negative effect or probability of the risk, or even accepting some or all of the potential or actual consequences of a particular risk. 
Certain aspects of many of the risk management standards have come under criticism for having no measurable improvement on risk, whether the confidence in estimates and decisions seem to increase.

\section{ABOUT APPLE}

Apple Inc. is an American multinational corporation that designs and manufactures consumer electronics, computer software, and personal computers. The company's best-known hardware products include Macintosh computers, the iPod, the iPhone and the iPad. Apple software includes the Mac OS X operating system; the iTunes media browser; the iLife suite of multimedia and creativity software; the iWork suite of productivity software; Aperture, a professional photography package; Final Cut Studio, a suite of professional audio and film-industry software products; and Logic Studio, a suite of audio tools.

Established in Cupertino, California on April 1, 1976 and incorporated January 3,1977, the company was called Apple Computer, Inc. for its first 30 years, but dropped the word "Computer" on January 9, 2007 to reflect the company's ongoing expansion into the consumer electronics market in addition to its traditional focus on personal computers.

Apple now has 60,400 full time equivalent employees, up from 46,600 last year. The company also went from employing 2,800 full-time equivalent temporary employees and contractors to 2,900.36,000 employees are in the retail division, up from 26,500 last year.

Apple went from 317 stores at the end of fiscal 2010 to 357 stores at the end of fiscal 2011, an addition of 40 stores. The average number of employees per store also grew from 83.6 to 100.8 .

Ad spending grew from $\$ 691$ million to $\$ 933$ million, while dropping as a percentage of revenues to $0.8 \%$ from $1.0 \%$. Research and development expenses were up 36\% to $\$ 2.4$ billion -- however, as a percentage of revenues R\&D fell from 3\% to $2.2 \%$.

Apple also lists a number of risk factors that could affect investments in the company. These include if Apple is found to have infringed on intellectual property rights, support from third-party software developers, the Company's ability to obtain components in sufficient quantities, and numerous more.

As of September 24, 2011, the Company owned or leased approximately 13.2 million square feet of building space, primarily in the U.S., and to a lesser extent, in Europe, Japan, Canada, and the Asia-Pacific regions. Of that amount approximately 7.0 million square feet was leased building space, which includes approximately 3.0 million square feet related to retail store space. Of the Company's owned building space, approximately 2.6 million square feet that is located in Cupertino, California will be demolished to build a second corporate campus. Additionally, the Company owns a total of 584 acres of land in various locations. Finally, the Company 
anticipates that for the foreseeable future it will retain any earnings for use in the operation of its business rather than paying any dividends or stock buybacks.

For reasons as various as its philosophy of comprehensive aesthetic design to its distinctive advertising campaigns, Apple has established a unique reputation in the consumer electronics industry. This includes a customer base that is devoted to the company and its brand, particularly in the United States. Fortune magazine named Apple the most admired company in the United States in 2008 and in the world in 2008, 2009, and 2010.

\section{APPLE' S RISK MANAGEMENT STRATEGIES}

Apple is engaged in one of the biggest industry in the world, where in there are many competitors who are offering the same or related products and services. That is the reason why the company is facing its major risk that is connected to the aggressive competition in the market. Competition is always one of the most important as well as the biggest risks in the business. Competitors are all battling it out in order to control the bigger segment or part of the market (Zajas \& Church 1997, p. 252).

Another important risk that the company will be facing in the future is the changing buying behavior of their target customers due to the changing condition of the global economy as well as the respective local economies of their target customers. The financial capability of their customers is also changing due to the said matter, and it has as great impact to the image of the products in the market. The said condition can even cause the customers to switch to other brand.

Another important thing is the growing incidents of fake and pirated products. This is one of the most important and growing risk for any company in the world, more specifically those who are involved in the electronic and computer industry. This is due to the fact that those products can be major competitors because they will offer lower price compare to the original, at the same time it can also cause bad image to the company, because it has the brand of the company.

The said risks are the most important threats that the company will be facing that will later on lead to another serious problem. That is why, the company must pay attention in order to ensure its position in the global market, and more particularly maintain the loyalty of their customers.

\section{BRANDING}

In terms of the problem regarding the increasing and ever-growing competition in the global industry, branding is its primary strategy. Branding is considered as one of the most efficient marketing tools that are used by many companies for 
their products and services. It can be defined as the process or method of creating a good connection or relationship between the company or the brand and the customer, in order that when the customers have a need, they will be able to think of a given product in order to satisfy their needs or demands (EBay, 2008). Furthermore, it can also be defined as the process of creating a connection between the given symbols, purpoces as well as passions and insights with the products and the services of the company, with its goal to drive loyalty from the customers that will later on create a huge differentiation from its competitors (Hislop, 2001, p. 6).

Apple is focusing on its activities in branding as well as to enables recognition from their customers. It is the process where in the company had been able to catch the attention of their customers and furthermore let the customers bring to their mind or bear in minds the products, whenever they are in need. Apple, particularly its iPod is considered as one of the most loved brand in the world. Branding is being used by the company in order to maintain its position in the market.

The said marketing strategy is important because it creates an important competitive advantage or edge for the company against its other competitors. Furthermore, it also helps the company for the future threat for new competitors due to its connection to its customers.

\section{INNOVATION}

Another important strategy of the company is its innovation process. It is important due to the fact that human are naturally insatiable, it means that the customers will ask for more and will need more for a given product. According to the CEO of the company, Steve Jobs, innovation is one of the most important processes that are being focused by the company. That is why they are hiring people who want to make the best thing in the world. Another thing is that their human resource are doing their best in order to make products that will come out the best that it can be (BusinessWeek, 2004).

In addition to that, innovation process of the company also enables them to gain the trust and loyalty of their customers by improving the relationship and connection of their products to their customers. According to Steve Jobs, the primary reason for the loyalty of their customers is that when they buy their products, three months later they will get stuck on something, that they will quickly figure out that the company actually did the said features or innovation. Furthermore, after three months, the company will launch another product that will have another or additional features that will again surprise the customers (BusinessWeek 2004). The said continuing process will maintain the interest of their customers.

By means of innovation, it can help the company to manage the different risks and problems that can be faced with regards to the issue of the threats for new entry as well as the threat for substitutions. The loyalty of the customers will be a great 
weapon of the company in order to manage the different problems that can affect their position in the market. Due to the fact that the innovation processes of the company enables their customers to be satisfied that will make it hard for the new competitors to enter in the same industry.

\section{RISK MANAGEMENT PROBLEMS OF APPLE}

One of the most not managed or not focused risks that are faced by the company is the pricing strategy. As of now, due to the ever-changing and ups and downs in the global economy, as well as the increasing numbers of fake Apple products that are available for low price in the market, it can affect the overall performance of the company.

In terms of fake products, the company must able to monitor all of the entities from its supply chain in order to make sure that all of the software as well as the overall structure of their products will not be copied and be reproduced. Furthermore, the company must also set a standard or a unique trademark, symbol or part that cannot be copied or reproduce in the part of their products in order to inform the product about the original and fake products. Furthermore, the company must be able to create and published different advertisement or notice to their customers in order to inform them regarding the issue of fake products.

Another important issue is the pricing strategy of the company, iPod and other products of the company are also considered as luxury brand. This will affect the overall performance of the company in terms of sales due to the fact that it offers high quality products but in high price. The said situation of the company can give other competitors some competitive advantage in terms of price. This is due to the fact that there are other countries or market that are price sensitive who prefer to buy or avail products and services that are low in price but has a high quality. In those terms, the company must able to create and produce products that will target the said important segment of market. It must be able to manufacture product that will be accessible and available for the mass or for the lower class level to avail the product, at the same time offering product that is high in quality in order to maintain the image of the company in the market.

On the other hand, the company must also maintain its image in the market as one of the luxury products and as one of the most sophisticated electronic company in the global industry. This is to maintain the loyalty of its other customers who belong to the upper class of the society. The company must be able to have different products and services that will handle the different level of income or social status. It will help the company to gain more market as well as to prevent the risk of the presence of the fake products that will serve as the nearest competitors of the company. 


\section{INSTEAD OF CONCLUSION: LEARNING OUTCOMES}

One of the most important things is about the different risk that can be faced and can affect the overall performance of any companies in any industries in global as well as in local market. Another important thing is that risk can affect the position of the company in the market as well as its relationship with its customers. That is the reason why it is important for any company to have its own different strategies in order to manage well the risks that might affect their overall performance.

In application to the real life, risk is just like air, it's everywhere, anything we do, we plan and we decide, there will be a risk that might affect its result or outcome. That is why it will be important to analyze all of the possible risk or threat that might cause future problems before doing or deciding about something. Risk management gives idea regarding the decision-making processes as well as in managing and organizing daily life with connection to business as well as other personal issues. The popcorn analysis also enables to give me more ideas regarding the different advantages and disadvantages in order to gain competitive advantage in any given market.

On the other hand, one thing that helped me in my process of learning in this module is the process of researching and analyzing the case studies that have been given to us. The said activity enables me to work on my own, and study using my own knowledge and then show my own perspectives and own ideas regarding the different issues that are associated in the course of the study. Furthermore, different books, journals, online journals and different websites also helped me to learn more regarding the issues and then create my own conclusion about it. Above all, the ideas and concepts of the Porter's Five Forces, enables me to focus more on the different threats that might cause risks to any company in any industry.

For future classes, it will be important to focus more on the different cases or situations that are related to the subjects in order to compare the different situations and the different aspects that might helped the students to understand more about the actual or the real world applications of the different theories that are related to the issues that are being tackl It will also helped the students to develop their ability to critically analyze and evaluate the different factors that are directly as well as indirectly associated or related to the core issue. In addition to that, it will also be important to have more individual as well as group activities in order to develop the independency as well as the theme of team work. By doing the said activities, it will help the students to work on their own as well as to work as a team, improving their relationship with other people.

\section{REFERENCES}

Airmic / Alarm / IRM (2010) "A structured approach to Enterprise Risk Management (ERM) and the requirements of ISO 31000". 
http://www.theirm.org/documents/SARM FINAL.pdf

Clapp, J., Dauvergne, P. (2005), Paths to a Green World: The Political Economy of the Glo- bal Environment, MIT Press.

Culp, C. (2001), The Risk Management Process: Business Strategy and Tactics, Wiley, New York.

Frame, J.D. (2003), Managing risk in organizations: a guide for managers, JosseyBass, San Francisco.

Franklin, J. ( 2001), The Science of Conjecture: Evidence and Probability Before Pascal, Johns Hopkins University Press, Baltimore.

Gottinger, H. (2003), Economies of network industries, Routledge, New York.

Hislop, M. (2001), "Branding 101: An Overview of Branding and Brand Measurement for Online Marketers", Dynamic Logic, viewed 27 May 2008,

Lant, T.K., Shapira, Z. (eds.) (2001), Organizational cognition: computation and interpretation, Lawrence Erlbaum Associates Mahwah, New York.

Lerbinger, O. (1997), The crisis manager: facing risk and responsibility, Lawrence Erlbaum Associates, Mahwah, New York.

Luhmann, N. (1993), Risk: A sociological theory, Aldine De Gruyter, New York.

Meyer, D.J. (2003), The economics of risk, W.E. Upjohn Institute for employment research, Kalamazoo, MI.

Moteff, J. (2005), Risk Management and Critical Infrastructure Protection: Assessing, Integrating, and Managing Threats, Vulnerabilities and Consequences (Report), Congressional Research Service, Washington DC, http://opencrs.com /document/RL32561/2005-02-04

Oxford English Dictionary Standards Association of Australia (1999), Risk management, S.A.A., North Sydney.

Volberda, H.W. (1999), Building the flexible firm: How to remain competitive, Oxford University Press, Oxford.

Zajas, J., Church, O. (1997), Applying Telecommunication and Technology from a Global Business Perspective, Haworth Press.

“The Seed of Apple's Innovation” (2004), BusinessWeek, viewed 27 May 2008, 